\title{
PHYSICS OR METAPHYSICS? Some Remarks on Theory of Science and Light in Robert Grosseteste*
}

Andreas Speer*

SINTESE - O bispo inglês Robert Grosseteste é um dos nomes mais importantes da ciência no século XIII. O tema da "luz" merece um tratamento especial, por parte deste autor, de quem se diz que desenvolveu uma verdadeira "metafisica da luz", que permitiu a passagem de Platão para Aristóteles, no que se refere à ciência natural.

\begin{abstract}
As one of the most important scientists in the thirteenth century emerges the name of the English bishop, Robert Grosseteste. A special study he has dedicated to the "light", developing, as it is usual to say, a true "metaphysics of light". Thus he made possible the transition from Plato to Aristotle, with regard to the natural science.
\end{abstract}

Throughout the spiritual and cultural history of mankind, the phenomenon of light has exercised a special fascination. The many names for light in the Middle Ages reflect the manifold nature of the subject: words such as lux, lumen, fulgor, radius, ardor, splendor, or claritas. ${ }^{1}$ This manifold is matched by the varieties of conception. Yet there are common presuppositions, which in general are regarded as distinct from the Aristotelian tradition. For the motifs of light and the speculation about light in the Middle Ages are to be viewed first of all in the context of the influences of the Neoplatonic tradition, enriched by Biblical motifs; they may take the form of a conception of similarity, as in Augustine, or they may follow the path of Pseudo-Dionysios, with his unitarian concept. ${ }^{2}$ In addition, the Biblical

* This paper is given at a conference on "Aristotle in Britain during the Middle Ages" from 8-10 April 1994 in Trinity College Cambridge under the auspices of the S.I.E.P.M., and will be also published in the proceedings, edited by John Marenbon.

** Thomas-Institut-Colônia (Alemanha)

1 Cf. J. Koch, Über die Lichtsymbolik im Bereich der Philosophie und der Mystik des Mittelalters, in Studium Generale 13 (1960), p. 653-670, see p. 654; cf. also W. Beierwaltes, Licht (Antike, Mittelalter und Renaissance), in Historisches Wörterbuch der Philosophie 5 (Basel 1980). p. 282-286.

2 Cf. K. Hedwig, Sphaera lucis. Studien zur Intelligibilität des Seienden im Kontext der mittelalterlichen Lichtspekulation, Münster 1980, p. 44-45 (Beiträge zur Geschichte der Philosophie und Theologie des Mittelalters N.F. 18).

\begin{tabular}{|l|l|l|l|l|l|}
\hline VERITAS & Porto Alegre & v. 41 & $\mathrm{n}^{\mathrm{e}} 163$ & Setembro 1996 & p. $411-422$ \\
\hline
\end{tabular}


treatment of the light motif also points in two directions, as it were; and these run across the Neoplatonic types already mentioned. Thus light is an essential cosmogonic factor in the Genesis creation account, while St. John gives us the equation of light, truth and life. Not surprisingly, then, the Genesis commentaries occupy themselves with the light theme. However, the initial approach (Augustine's, for example) generally adopts the perspective of St. John: heaven (caelum) is interpreted not cosmologically, as a phenomenon of nature, but rather as an intelligible region of knowledge, openness, transparence and community of contemplation "face to face"; a region where the created beings that are capable of contemplation, immersed in the original light without shadow or obscurity, themselves become light. $^{3}$ The earth (terra), on the other hand, appears as the region of material bulkiness, existing only by virtue of its orientation towards the form-giving form (forma omnium formarum). ${ }^{4}$

Now, what is the connection between the picture just sketched and the subject of this volume, "Aristotle in Britain during the Middle Ages"? There is indeed a connection; I hope to show it in the course of this paper, whose subject will be Robert Grosseteste. The figure of my protagonist betrays the peculiar approach to Aristotle that will come to light. My concern is, How did Aristotle come to Britain? The light motif may be surprising in this context, being more usually associated with Platonism; but we cannot ignore it if we wish to answer our question. For inquiry into the reception of Aristotelian writings must also deal with the motives behind the move away from Plato and towards Aristotle that accompanied the comprehensive appropriation of the body of Aristotle's works. To ascribe this move solely to the rapid growth of translation activity in the twelfth century, is to ignore historical fact. Indeed, the delay relation between the translation of Aristotelian works and their reception makes it appear more probable that translation was the effect, and not the cause in this relation. What we must look for is the philosophical motivation that led to the heightened interest in Aristotle's writings. ${ }^{5}$

If we now glance at Robert Grosseteste's tract, De luce seu de inchoatione formarum, we shall find ourselves at the heart of the matter. This tract is considered to be a paradigm of mediaeval light metaphysics. ${ }^{6}$ Among the available works of Grosseteste, it represents a watershed. Written between 1225 and 1228, the tract is characterized by indisputably Platonic language use and reasoning; but it also marks the beginning of an intensive occupation with Aristotle's works on Grosseteste's part. He began with Aristotle's writings on natural philosophy and the theory of science. A first result of this comprehensive work of reception is to be seen in the commentaries to the Physics and the Posterior Analytics, written between 1228

3 Augustinus, De genesi ad litteram I, 1, 3; ibid., I, 17, 32; Confessiones XII, 9, 9; ibid. XII, 15, 20.

4 Augustinus, De genesi ad litteram I, 1, 3; ibid., I, 4, 9; cf. K. Hedwig, op. cit., p. 38.

5 See A. Speer, Reception - Mediation - Innovation. Philosophy and Theology in the 12th Century, in Bilan et perspectives des études médiévales, ed. J. Hamesse, Louvain-la-Neuve 1994, p. 129-149 (Actes du premier congrès eưropéen d'études médiévales, Spoleto 27-29 mai 1993).

6 See J. McEvoy, Ein Paradigma der Lichtmetaphysik: Robert Grosseteste, in Freiburger Zeitschnift für Philosophie und Theologie 34 (1987), p. 91-110; McEvoy deals foremost with "De luce". 
and $1232{ }^{7}$ Also around this time, and within the same systematic context, Grosseteste produced his Hexaëmeron, which is written in the literary tradition of Genesis's exegesis. Now, in the Prooemium of his Hexaëmeron, Grosseteste had invoked Ambrosius, and especially Augustine. ${ }^{8}$ But change was in the air, in the twelfth century; a combination of inner and outer circumstances was leading to a fundamental shift in the understanding of nature, one that Marie-Dominique Chenu aptly identified as "la découverte de la nature", the discovery of nature. ${ }^{9}$ Under the influence of texts on science and on natural philosophy, texts inherited from Roman antiquity and from the Arab world, the symbolic-speculative understanding of nature begins to wane in the twelfth century. Its place is increasingly usurped by an interest in the structure, make-up and regularity of physical reality. In the school of Chartres, for example, this physical reality begins to be understood "secundum physicam" as an "ordo naturalis" along the lines of Plato's Timaeus and the Opuscula sacra of Boethius, both "rediscovered" at the outset of that century. ${ }^{10}$ So too Grosseteste, at the beginning of his Hexaëmeron exegesis, determines that the "primus sensus Iitere principii huius scripte" is the inquiry into the creation and structuring of the visible corporeal world, taking place in time ("de creatione temporali et successive corporalium et visibilium celi et terre, et visibilis ornatus eorum") following the "creacio ex nihilo". This discovery of nature is accompanied by an "éveil métaphysique", to take up yet another term from Chenu; ${ }^{11}$ that is, a reflection on principles and the possibility of their justification, with respect to a natural universe. In the first quarter of the thirteenth century, both these tendencies provide a foundation for the reception of Aristotle's "libri naturales". ${ }^{12}$

\section{II}

This gives us the context within which we must now consider Robert Grosseteste's tract De luce. Despite the predominant influence of Peripatetic motifs, especially in the cosmogony, James McEvoy rightly calls this tract a speculative Genesis exegesis, pointing to the evident parallels to the teachings of the masters of Chartres. ${ }^{13}$ Departing from his practice in the Hexaemeron commentary, Grossetes-

7 Cf. J. McEvoy, The Chronology of Robert Grosseteste's Writings on Nature and Natural Philosophy, in Speculum 58 (1983), p. 614-655, see p. 648-654.

8 See Robert Grosseteste, Hexaëmeron, prooemium 1, 15, 57-58 (ed. R. Dales and S. Gieben, Oxford 1982), p. 17,21-22,32 (Auctores Britannici Medii Aevi VI).

9 M.-D. Chenu, La théologie au douzième siècle, Paris $1957,{ }^{3} 1976$, p. 18-21.

10 Cf. A. Speer, Reception - Mediation - Innovation (op. cit.), p. 131-132 and p. 137-140; see also the very instructive introduction of P. E. Dutton, "The Glosae super Platonem" of Bernard of Chartres, Toronto 1991, p. 1-8 (Studies and Texts 107).

11 M.-D. Chenu, op. cit., p. 19-51 and p. 309-322.

12 Cf. A. Speer, Natur, in Lexikon des Mittelaiters VI/5 (1992), p. 1040-1043, see p. 1041-1042; in great detail cf. id., Die entdeckte Natur. Untersuchungen zu Begründungsversuchen einer "scientia naturalis" im 12. Jahrhundert, Leiden-Köln 1995 (forthcoming), chapter VI (Studien und Texte zur Geistesgeschichte des Mittelalters).

13 J. McEvoy, Ein Paradigma der Lichtmetaphysik (op. cit.), p. 98; cf. also the introduction of R. C. Dales, Roberti Grosseteste commentarius in VIII libros Physicorum Aristotelis, Colorado 1963, p. XX$\mathrm{XXI}$. 
te here is no longer to be seen following the Biblical wording "literaliter". Instead, as so often in his tracts, he straightaway introduces the central thesis to be investigated and developed, rather after the manner of a quaestio. "I believe", so Grosseteste begins, "that the first corporeal form, which some call corporeality (corporeitas), is light". ${ }^{14}$ "Now corporeality means", so Robert continues, "that which is necessarily accompanied by the spatial extension (extensio) of matter in three dimensions, even while both, corporeality and matter, are a simple self-contained substance with no dimension" ${ }^{15}$ Thus he names the starting point for the cosmogony that follows: on the one hand, the form of all corporeality, interpreted as light, and on the other hand matter. As Grosseteste elaborates in his Hexaëmeron, both were simultaneously created "ex nihilo" and are not to be separated objectively. ${ }^{16}$ Light, by nature being the "primum motivum corporale" and as such radiating, or multiplying itself in all directions, in this way expands the matter it cannot objectively leave, introducing into it the three dimensions. ${ }^{17}$ It is this capacity to radiate and to expand that marks light as the first corporeal form. Conversely, the first corporeal form must be light, because it is light which, in accordance with its diverse reproductions, builds up the substantial, basic structure of things on the one hand, and, on the other hand as the extending power, builds up the cosmos. In doing so, light draws matter apart into a gigantic volume corresponding to that of the entire "machina mundi"; and this takes place "in principio temporis", that is, after the manner of an instantaneous, timeless and all-encompassing radiation. ${ }^{18}$

It is evident that Grosseteste is here continuing a twelfth-century discussion that took place predominantly at Chartres. This discussion regarded the theoretical foundation for natural philosophy, motivated by cosmological questions. The questions are similar to those that arise from a confrontation of Genesis with Timaeus: the ground of creation, the originator of the cosmos, the creation of matter, the creation of the world in time, the uniqueness of the world, and the relation between mundus archetypus and mundus sensibilis. Here light, as corporeitas or prima forma corporalis, is a limit concept in the theoretical discussion of the principles of the natural, physical world: it explains the creation as an "educcio rei in esse ex nihilo". ${ }^{19}$

14 De luce seu de inchoatione formarum, ed. L. Baur, Die philosophischen Werke des Robert Grosseteste, Bischof von Lincoln, Münster 1912 (= Beiträge zur Geschichte der Philosophie und Theologie des Mittelaiters IX), p. 51,10-11: "Formam primam corporalem, quam quidam corporeitatem vocant, lucem esse arbitror."

15 De luce (ed. Baur), p. 51,13-16: "Corporeitas vero est, quam de necessitate consequitur extensio materiae secundum tres dimensiones, cum tamen utraque, corporeitas scilicet et materia, sit substantia in se ipsa simplex, omni dimensione carens." Hexaëmeron II, 5, 5 - 6, 1 (ed. Dales/Gieben), p. 92-93; ibid., II, 10, 1-2 (ed. Dales/Gieben), p. 97-99. De luce (ed. Baur), p. 52,3-9; ibid., p. 52,16-21: "Lux ergo, quae est prima forma in materia prima creata, seipsam per seipsam undique infinities multiplicans et in omnem partem aequaliter porngens, materiam, quam relinquere non potuit, secum distrahens in tantam molem, quanta est mundi machina, in principio temporis extendebat."

Hexaëmeron I, 11, 1 (ed. Dales/Gieben), p. 67. Concerning the twelfth-century discussion cf. A. Speer, Die entdeckte Natur (op. cit.), in particular chapter VI. 
It is further evident that Grosseteste's deliberations are closely interwoven with questions of method and theory of science, as were the twelfth century attempts to found a "scientia naturalis". For an example, we shall consider the radiation of light, which Grosseteste explains by means of a model of mathematical infinity. A unity (unitas), originally possessing no spatial dimensions, can only create the dimensions by means of endless multiplication or radiation. In like manner "light, by its own infinite radiation, evidently expands matter into lesser and greater finite dimensions built up of an arbitrary number of numerical and non-numerical proportions that stand in some relation to one another" ${ }^{20}$ This multiplication or radiation must be infinite, for only so can the entire cosmos be derived from one single principle. Yet what results from this infinite multiplication of unity is not itself infinite: the endless multiplication is quantitatively determined as light expands matter into the finite dimensions of size ${ }^{21}$ Grosseteste cites two reasons for this. The first reason is of a theoretical nature and derives from the following axiom: that the simple is infinitely greater than even the greatest infinite. ${ }^{22}$ Grosseteste explicates this principle by recourse to arithmetical proofs in the course of a far-reaching excursion that is comparable, for example, to the work of Thierry of Chartres in his tract on the six days of creation. The essence of the proof is this. Seen mathematically, unity is indivisible. When it is multiplied to generate the numbers and number sequences, unity itself is not thereby affected; what is affected are those entities that participate in unity after the manner of this multiplication, indeed owe their non-unitary existence to unity. Understood numerically, unity - as the one - is not the first number, but rather the principle of number, as it is contained in all the other numbers. ${ }^{23}$ In just the same way light, as the first corporeal form, is contained in all corporeal beings. According to Boethius, the method of mathematical proof, having as its object that which is without motion yet nonabstract, builds a bridge, as it were, between theology (we might say, more precisely, speculative theologics), which is concerned with that which is without motion and abstract, and physics, which is concerned with that which is in motion and non-abstract. ${ }^{24}$ This method demonstrates the significance of light, conceived

20 De luce (ed. Baur), p. 53,27-30: "His ergo ita se habentibus est, quod lux multiplicatione sua infinita extendit materiam in dimensiones finitas minores det dimensiones finitas maiores secundum quaslibet proportiones se habentes ad invicem, numerales scilicet et non numerales."

Cf. Thierry of Chartres, Tractatus de sex dierum operibus, 29-43, ed. N. M. Häring, Commentaries on Boethius by Thierry of Chartres and his School, Toronto 1971, p. 567,72-573,39 (= Studies and Texts 20); cf. É. Jeauneau, Mathématique et Trinité chez Thierry de Chartres, in P. Wilpert (ed.), Miscellanea Mediaevalia 2: Metaphysik im Mittelalter, Berlin 1963, p. 289-295; see also A. Speer, Die entdeckte Natur (op. cit.), chapter V,4.

De luce (ed. Baur), p. 52,29-31: "Lux igitur, quae est in se simplex, infinities multiplicata materiam similiter simplicem in dimensiones finitae magnitudinis necesse est extendere." De luce (ed. Baur), p. 52,28-29: "Quantum enim infinitum infinities infinite excedit simplex."

23 Cf. Thierry of Chartres, Tractatus de sex dierum operibus 33 (ed. Hring), p. 569,22-25; see É. Jeauneau, op. cit., p. 290-291.

24 Cf. Boëthius, De Trinitate II (ed. H. F. Stewart/E. K. Rand/S. J. Tester, LCL 74), p. 8; Thierry of Chartres, Lectiones in Boethii librum de Trinitate, II,18-32 (ed. Häring, Commentanies on Boethius), p. 160, 9-165,88; A. Speer, Reception-Mediation - Innovation (op. cit.), p. 141-143. 
as unity and simplicity, as the principle of the domain of corporeal beings. It follows that the infinite extension of light cannot be related to the finite dimensions, which derive from the extension of matter, just as the subtraction of a finite number from an infinite number cannot be stated as a numerical relation. ${ }^{25}$

The second, physical reason why the extension of matter through the infinite multiplication of light should lead to quantitative determination has to do with the manner in which light is bound to matter. Here Grosseteste takes up the cosmogony of light and develops it further. The instantaneous, timeless, infinite multiplication of light, as the first created corporeal form, is at once its own expanding power, effect and propagation; and it occurs in the manner of a sphere, "so that a single point of light suddenly gives rise to a light sphere of greatest possible size, unless it be opposed by something that throws a shadow" ${ }^{26} \mathrm{~A}$ light sphere is created, at whose periphery the potentiality of matter, being likewise simultaneously extended and thereby suffering a decrease in potentiality, becomes completely actuated. This equilibrium of light and matter gives rise to the first completely simple and active body, namely the firmament, which is composed only of light (the first form) and prime matter (as pure potentiality). ${ }^{27}$ Where this perfect balance of light and matter is reached, there ends the expansion of light, and with it the gradual formal actualization of matter; once this boundary is reached, the only remaining possibility is a return by reflection towards the centre of radiation. Klaus Hedwig aptly calls this the "cosmic reflective boundary". ${ }^{28}$ At this boundary, empirically visible light emanates from the "dematerialized" matter, as it were, of the heavenly body. ${ }^{29}$ Terminologically, this empirically visible, sensible light is sharply distinguished from the light principle as the first corporeal form. Grosseteste calls the latter "lux" while the former, the visible light proceeding from the firmament as the first body, is called "lumen". As "spiritual body" (corpus spiritualis) or "corporeal spirit" (spiritus corporalis), the light called "lumen" now, by an analogue procedure of multiplication/radiation, constitutes the matter found below the sphere of the firmament, beginning with the upper regions of heaven. ${ }^{30}$ The sublunar regions of the world are likewise part of the same universal order, founded in light (lux) as the formal cause of natural process.

We have now seen light as "corporeitas" and thus as principle of the natural, physical processes of the "machina mundi", illustrated using the De luce system as a guideline. The same might be said of the Hexaëmeron and the commentary on the Physics. For corporeal being, light is the genus generalissimum, as

25

26

27

28

29

30

De luce (ed. Baur), p. 53,18-23.

De luce (ed. Baur), p. 51,11-13: "Lux enim per se in omnem partem se ipsam diffundit, ita ut a puncto lucis sphaera lucis quamvis magna subito generetur, nisi obsistat umbrosum." - Cf. ibid., p. 54,18-21.

De luce (ed. Baur), p. 54,21-24: "Et sic perfectum est corpus primum in extremitate sphaerae, quod dicitur firmamentum nihil habens in sui compositione nisi materiam primam et formam primam."

K. Hedwig, op. cit., p. 137.

De luce (ed. Baur), p. 55,1-3: "Et sic procedit a corpore primo lumen, quod est corpus spirituale, sive mavis dicere spiritus corporalis."

De luce (ed. Baur), p. 55,8-17. 
it were. ${ }^{31}$ As a single point of light specifies uniform expansion into a spherical body, so the simple essence of light contains the different lines and proportions of formed bodies. In this way the "figura corporalis" can be described, as far as its causes are concerned ("causaliter"), by means of a single point. ${ }^{32}$ This is fundamental to understanding Grosseteste's concept of physics as a scientia naturalis that asks after measure, time and motion. His understanding of light founds not only the geometrically determinate nature of the corporeal form of things, but also his cosmogony of light, which is described as an expansion process that can be geometrically determined in all its phases in accordance with the laws of the sequence of dimensions and the countable proportions. In this manner, natural processes can be interpreted following the geometry of light propagation. Accordingly, geometrical optics (scientia perspectivae) assumes the character of a model science in which the general regularity of nature can most perfectly be discerned. "All causes of natural events," writes Grosseteste in the tract De lineis angulis et figuris seu de fractionibus et reflexionibus radiorum, "can be given (dari) by lines, angles and figures. For in no other way can their ground and the explanation of their effectiveness (propter quid) be known" ${ }^{33}$ No natural philosophy can therefore afford to ignore this geometrical-optical method. ${ }^{34}$

\section{III}

What of the relations between the individual sciences? Alistair C. Crombie sees the basis for the close connection between mathematical and experimental method (exemplified by optics and astronomy) in a mathematical Platonism, in analogous fashion to the model of modern quantitative physics. ${ }^{35} \mathrm{McEvoy}$ justly warns against Crombie's wish to see in De luce a paradigm of modern mathematical-experimental science; in his turn, however, he identifies a number of areas in which Grosseteste anticipates the natural philosophy and the science of early modern times. ${ }^{36}$

There remain nonetheless weighty differences, of which the central one is this. For Grosseteste, the universal applicability of mathematics and geometry to the study of nature is possible because everything is created of light. This confronts us with Grosseteste's grand design, and gives us the occasion critically to evaluate it. The central principle can only be interpreted as a metaphysical assumption. For

31 Cf. Hexaëmeron I, 18, 2 (ed. Dales/Gieben), p. 78,6: "omnis enim forma aliquod genus lucis est". Commentanius in VIII libros Physicorum I (ed. Dales), p. 15: "omnis igitur substancia corporea que alicubi est secundum substanciam tota ubique et ita omnia est".

Commentarius in VIII libros Physicorum I (ed. Dales), p. 53 and 55; ibid. IV (ed. Dales), p. 97.

De lineis, angulis et figuris (ed. Baur, Die philosophischen Werke des Robert Grosseteste), p. 60,1416: "Omnes enim causae effectuum naturalium habent dari per lineas, angulos et figuras. Aliter enim impossibile est sciri 'propter quid' in illis." Cf. De lineis, angulis et figuris (ed. Baur), p. 59,17-60,1: "Utilitas considerationis linearum, angulorum et figurarum est maxima, quoniam impossibile est sciri naturalem philosophiam sine illis."

35 See A. C. Crombie, Robert Grosseteste and the Origins of the Experimental Science, 1100-1700, Oxford 1953, chapter V, p. 91-127, and ibid., p. 132-134.

36 J. McEvoy, Ein Paradigma der Lichtmetaphysik (op. cit.), p. 99; id., The Philosophy of Robert Grosseteste, Oxford 1982, p. 180-188. 
Grosseteste, then, speculation about light leads to a metaphysics of light, inspired by physics. This widely respected theory regarding Grosseteste's metaphysics of light is shared by Crombie; it is based on the equivalence of physical light and spiritual light, in analogue fashion to the unity of the "principia essendi" and the "principia cognoscendi". This metaphysics of light is, for Crombie, the framework within which Grosseteste's individual contributions to a theory of experimental science should be seen. ${ }^{37}$

James McEvoy shares this view; like Alistair C. Crombie, he adduces in particular Grosseteste's commentary on the first book of the Posterior Analytics and the Hexaëmeron. ${ }^{38}$ Yet it is precisely in McEvoy's case that the problematic nature of such a conception of the metaphysics of light becomes particularly clear. McEvoy correctly speaks of an analogue concept of light, which does not lose its unity of content but rather applies to different types of being; and he argues for the unity of a metaphysical concept of light against its reduction to mere metaphor. ${ }^{39}$

Now, it must be asked whether an analogous concept can become the subject of a science. This question points the way to a test I would propose for the hypothesis that Grosseteste's speculation about light can be termed a metaphysics of light. For such a test, we must start with a discussion of the subject of a science, taking as our example an early witness, Grosseteste's commentary on the Analytica posteriora. The subject of a science is that which makes it to be this particular science and distinguishes it from all others; this unambiguous test decides the legitimacy and the nature of the science. In addition to this proper subject, there can also be other subjects in a science, but these do not make up the distinctive side of the science. ${ }^{40}$

If we accept this test, then we can only speak of a metaphysics of light in Robert Grosseteste's writings in a substantially reduced sense. In De luce the attempt is made to show that knowledge of the most general structures of being is possible using a concept of light (lux) as the first corporeal form, measurable in accordance with the laws of optics. This attempt can properly be said to succeed only in the realm of natural philosophy, as it has its origin there. Only in the systematic context of natural philosophy does the concept of light possess the consistency necessary to act as a basic concept and principle. Only proceeding from physics is it possible to use the concept of light in the sense of a relation of subalternation ("per modum scientia subalternatis"), which distinguishes Grosseteste's understanding of science; this is what makes it possible, with the aid of mathematical abstraction, to resolve (resolutio) the forms of being in their material constitution into their

37 Cf. A. C. Crombie, op. cit., p. 128-134.

38 See Commentarius in Posteriorum Analyticonum Libros, I, 7 (ed. P. Rossi, Firenze 1981), p. 140,112130; ibid., I, 17 (ed. Rossi), p. 240,38-241,47; Hexaëmeron II, 10, 1 (ed. Dales/Gieben), p. 97,22-98,25. Cf. A. C. Crombie, op. cit., p. 128-131; J. McEvoy, Ein Paradigma der Lichtmetaphysik (op. cit.), p. 102-103 and 106-107.

39 J. McEvoy, Ein Paradigma der Lichtmetaphysik (op. cit.), p. 107 and 110. The structure of McEvoys detailed study about The Philosophy of Robert Grosseteste (op. cit.) is based on this unitarian concept of so-called light-metaphysics.

40 Cf. A. Zimmermann, Ontologie oder Metaphysik? Die Diskussion über den Gegenstand der Metaphysik im 13. und 14. Jahrhundert, Leiden/Köln 1965, p. 88 (= Studien und Texte zur Geistesgeschichte des Mittelalters 8). 
founding principle. For the subject of a subalternate science (scientia subalternata) contains, as Robert extensively argues in his commentary on the Prior Analytics, the subject of that science to which it is subalternate. In this way the subject of the subalternating science (scientia subalternans) gives the condition for the subject of the subalternate science. At the same time the subalternate science adds something to the subalternating science, by way of a specifying and thus limiting condition. ${ }^{41}$ For example, if being in general is seen as the subject of metaphysics, then this also includes moved bodies, the subject of physics; but this does not necessitate that every being be a moved body. ${ }^{42}$ Subalternation thus only works in one direction, grounding a hierarchy of sciences according to their subject without putting into doubt the applicability of the respective sciences; this range must be determined with the particular method appropriate to the science. Grosseteste cites the example of a descendancy relation that obtains between the science of the elements ("scientia de elementis") and medicine, both of which have to do with elements. Yet medicine is not concerned with the human body "insofar as it is elements, but insofar as it is composed of elements". It follows that the elements cannot be the subject of medicine, although medicine cannot dispense with the principles of the science of the elements. ${ }^{43}$

This brings us back to the question regarding the relation between the individual sciences. Crombie saw them as being interconnected on the basis of a mathematical Platonism. ${ }^{44}$ This thesis, interlinked with the idea of a universally valid light metaphysics, has been put into question by W. R. Laird; he raises a fundamental objection by referring to the commentary on the Posterior Analytics and the Physics, pointing out instead "that Grosseteste's approach to these sciences is fundamentally Aristotelian". ${ }^{45}$ For clearly Grosseteste aims at a more precise determination of the derivative relation between the individual sciences than would have been possible in the models of scientific method based on Plato and Boethius. Such a determination of derivative relation is the prerequisite to integrating experimental and observational knowledge into a sufficiently consistent science that has demonstrative character. The Aristotelian teaching regarding the sciences offers a model for this sort of epideictic science and posits subalternation as the type of the relation between the sciences. This applies to the respective subjects of the sciences as well as to their manner of demonstration. As an example, the relation between pure mathematics and physics, or between both of them and the "intermediate sciences" of optics and astronomy, is investigated in the commentary on the

41 Commentanius in Posteriorum Analyticorum Libros, I, 8 (ed. P. Rossi), p. 148,45-149,66.

42 Commentarius in Posteriorum Analyticorum Libros, I, 18 (ed. P. Rossi), p. 261,41-49: "Scientia autem est subaltemata alii cuius subiectum addit conditionem super subiectum subalternantis, que conditio non est totaliter exiens a natura subiecti subalternantis, sed extra sumitur, velut radiositas non est aliqua natura totaliter exiens a natura magnitudinis, sed extra sumpta est. Similiter a natura entis, quod est subiectum metaphysice, non venit totaliter quod dico corpus mobile, quod est subiectum physice, quia in natura mobilis dico privationem et non ens quod est principium mobilis in quantum huiusmodi."

Commentarius in Posteriorum Analyticorum Libros, I, 12 (ed. Rossi), p. 195,148-196,171; cf. W. R. Laird, Robert Grosseteste on the Subalternate Sciences, in Traditio 43 (1987), p. 148-169, see p. 165.

44

45 Cf. A. C. Crombie, op. cit., p. 91-98.

W. R. Laird, , op. cit., p. 148. 
second book of the Physics. ${ }^{46}$ In his commentary on the first book of the Posterior Analytics Grosseteste discusses the conditions for applying abstract geometrical assertions within the "perspectiva" for demonstration purposes in the context of concrete observations or experiments. ${ }^{47}$ Here the usefulness of the Aristotelian theory of the sciences becomes evident; for it addresses those questions that arise from attempts to provide natural philosophy with a theoretical groundwork, in view of the immanent functional exigencies of sciences becoming increasingly differentiated.

\section{IV}

Most interpretations see Grosseteste's theory of knowledge as the second highlight of his treatment of the light theme. Now, seen from the standpoint of such a physically restricted metaphysics of light (and perhaps it would be better to speak simply of a physics of light), it would seem that it is only in the "sensualitas" of knowledge that this theory of knowledge can possess some unequivocal relevance to knowledge. Grosseteste himself, in the second part of his Hexaëmeron, sees only this possibility for linking the self-multiplying light as first corporeal form with the human power of knowledge. ${ }^{48}$ "Light is that whereby the soul operates in all its sense powers, and that which operates in these powers 'instrumentaliter ${ }^{\prime \prime} .{ }^{49}$ It is light which allows us to experience corporeal things by our senses, presenting them to our eyes in their dimensions and colours. "Without light, therefore, everything corporeal is hidden and unknown" ${ }^{50}$ Light is furthermore the beauty and ornation of all of visible creation; ${ }^{51}$ and this not as a reflection of otherworldly beauty, but as the direct pleasure that the senses take at the contemplation of harmonic proportions. $^{52}$

Apart from this restrictive usage of light terminology, Grosseteste also uses it in a wider epistemological sense. In the commentary on the Posterior Analytics he writes: "Things are called certain by virtue of the comparison they permit with knowledge or spiritual contemplation. Hence I say that there is a spiritual light (lux spiritualis) that is poured out upon the intelligible and upon the eye of the spirit. This light may be related to the inner eye and to the intelligible things as the corporeal sun is related to the corporeal eye and to the visible corporeal things. The more and intelligible thing is capable of receiving this spiritual light, the more it is visible for the inner eye. And an intelligible thing will be the more capable of recei-

46

47

48

49

\section{0}

Commentarius in VIII libros Physicorum II (ed. Dales), p. 36-38; cf. W. R. Laird, , op. cit., p. 151.

Commentarius in Posteriorum Analyticonum Libros, I, 8 (ed. Rossi), p. 149,66-150,89; cf. W. R. Lairf, op. cit., p. 157-158.

Summerizing Hexaëmeron II, 10, 1 (ed. Dales/Gieben), p. 97,22-98,25.

Hexaëmeron II, 10, 1 (ed. Dales/Gieben), p. 98,15-16: "Lux igitur est per quam anima in omnibus sensibus agit et que instrumentaliter in eisdem agit."

Hexaëmeron II, 10, 2 (ed. Dales/Gieben), p. 99,11: "Sine luce itaque omnia corporea occulta sunt et ignota."

51 Hexaëmeron II. 10, 2 (ed. Dales/Gieben), p. 99,14: "Lux igitur est pulcritudo et ornatus omnis visibilis creature."

52

Hexaëmeron II, 10, 4 (ed. Dales/Gieben), p. 99,20-100,11. 
ving this light as it resembles the essence of this light. Thus those things which are capable of receiving this light to a higher degree are fathomed more perfectly by the peak of the spirit, for this peak of the spirit is also a spiritual radiation. And this more perfect penetration is also a greater certainty."153

The semantics alone suffice to show the difference between this usage and the restrictive usage within the physical context. Grosseteste speaks of comparison (comparatio), of relation (se habere ad) and similarity (assimilari). Although these terms originally were used to designate mathematical ideas, Grosseteste uses them here "translative", that is, in a metaphorical manner. ${ }^{54}$ The language being metaphorical, light cannot be the proper object of these deliberations, and most certainly not after the manner of strict subalternation. Rather, light stands for something else. It can stand for truth (as "lux veritatis"), which, as an "adaequatio sermonis interioris et rei" ${ }^{155}$ in the tradition of Augustine's theory of illumination, warrants the certainty of knowledge in the knowing intellect and in the object of knowledge (cf. Bonaventura). Light also stands for the divine Word, which, as God's highest selfexpression ("Sermo Patris") is not only the original image of the Ideas, but also represents the absolute "adaequatio" in exemplary fashion. ${ }^{56}$ Finally, light can stand for God himself as "prima forma et forma omnium" if we accept the basic postulate that the principles of being and of knowledge coincide ${ }^{59}$ we must face the question as to whether we can really conceive natural light on the one hand and the light which illuminates the intellect on the other as being in some way coherent. Certainly the requirements to be fulfilled by the subject of a science speak against it, as does the claim for a strictly derivative relation between the sciences' subjects, after the manner of subalternation. For, if light is only an analogous concept, then, as soon as it is applied to the different realms of being, it loses the conceptual unity that is indispensable for the metaphysical foun-

53 Commentarius in Posteriorum Analyticorum Libros, I, 17 (ed. Rossi), p. 240,38-241,47: "Res autem dicuntur certe a comparatione quam habent ad cognitionem sive ad visum mentalem. Dico ergo quod est lux spiritualis, que superfunditur rebus intelligibilibus et oculo mentis, que se habet ad oculum interiorem et ad res intelligibiles sicut se habet sol corporalis ad oculum corporalem et ad res corporales visibiles. Res igitur intelligibiles magis receptibiles huius lucis spiritualis magis visibiles sunt oculo interon, et magis sunt huius lucis receptibiles que nature huius lucis magis assimilantur. Res itaque huius lucis magis receptibiles ab acie mentis, que similiter est irradiatio spiritualis, perfectius penetrantus, et hec penetratio perfectior est certitudo maior."

Regarding the meaning of "tranlative" or "translativae locutiones" cf. Thierry of Chartres, Lectiones in Boethii librum de Trinitate IV, 13-15 (ed. Häring, Commentaries on Boethius), p. 190,44-191,75.

De veritate (ed. Baur), p. 134,23-24.

56

De veritate ( ed. Baur), p. 134,26-31: "Sapientia autem et verbum, sive Sermo Patris maxime adaequatur hoc modo adaequationis rei, quam dicit et loquitur. Ita enim est res quaeque plenissime, ut hic sermo dicit; nec in aliquo aliter est, ac dicitur hoc sermone; nec solum adaequatur, sed est ipsa adaequatio sui ad res, quas loquitur."

Cf. Bonaventura, Quaestiones disputatae de scientia Christi, qu. IV c (Quaracchi V 23b); A. Speer, Triplex veritas. Wahrheitsverständnis und philosophische Denkform Bonaventuras, Werl/Westf. 1987, p. 54-56 (= Franziskanische Studien 32).

De unica forma omnium (ed. Baur), p. 106,15-107,3.

58

59 Hexaëmeron IV, 1, 1 (ed. Dales/Gieben), p. 121,19-28.

Commentarius in Posterionum Analyticonum Libros, I, 7 (ed. Rossi), p. 140,129-130: "[...] sunt he causales rationes principia essendi et cognoscendi et sunt incorruptiblia." 
dation. To be able to speak of a subiectum metaphysicae, we should be compelled to replace the concept of light with one of the principles named and described by means of the analogous manifold of the light metaphor. With a view to the tracts "De unica forma omnium" and "De luce sive de inchoatione formarum", we might consider the concept of form as a candidate for the role of such a principle. This would allow us adequately to develop the connection between epistemology and physics that Crombie asserts on the basis of the metaphysics of light, as a metaphysics of form. But that is a subject for a different lecture.

On the other hand, the unity of content of the analogous concept of light so vigorously defended by James McEvoy ${ }^{60}$ would, in the final analysis, lead not to a metaphysics of light, but rather to a blurring of the distinction between metaphysics and metaphor. Robert Grosseteste rejected this path. Far more: the tract $D e$ luce demonstrates the evolution of a metaphysics of light in the strict sense, its subject defined in accordance with the Posterior Analytics. This metaphysics has its point of reference in natural philosophy or, more precisely, in the theoretical foundation for a scientia naturalis and motivated by cosmological questions. Grosseteste's tract thus admirably illustrates the philosophical motivation that will underlie the interest in Aristotelian writings and is to contribute to the transition from Plato to Aristotle. ${ }^{61}$ However, as for the subject of this metaphysics of light, namely light as the first corporeal form, the realm is drastically reduced. In this form, speculation about light passed on into the Oxford Physics commentaries after 1250 , where examples are to be found which show that the quest for the form principle or the first form (prima forma) of corporeal being, as well as for the substantialitas and the genus generalissimum make use of this same terminology of light. ${ }^{62}$

60 Cf. J. McEvoy, Ein Paradigma der Lichtmetaphysik (op. cit.), p. 106-109.

61 Cf. G. Wieland, Plato oder Aristoteles? Überlegungen zur Aristoteles-Rezeption des lateinischen Mittelalters, in Tijdschrift voor Filosofie 47 (1985), p. 605-630, see p. 616.

62 Cf. Anonymus, Questiones supra Physicam I-VIII (ms. Siena Biblioteca Comunale degli Intronati, L.III.21, ff.1ra-92ra), see S. Donati, Per lo studio dei commenti alla Fisica del XIII seculo. I: Commenti di probabile origine inglese degli anni 1250-1270 ca., in Documenti e Studi sulla Tradizione Filosofica Medievale II,2 (1991), p. 361-441, see p. 396-409; Anonymus, Questiones supra Physicam I-IV, VI (ms. Oxford, New College, 285, ff.118ra-162ra), see A. Zimmermann, Verzeichnis ungedruckter Kommentare zur Metaphysik und Physik des Aristoteles aus der Zeit von etwa 1250-1350, Band I, LeidenKöln 1971, pp. 33-35 and 259-268 (= Studien und Texte zur Geistesgeschichte des Mittelalters IX); Anonymus (- Galfridus de Aspall), Questiones super Metaphysicam (ms. Cambridge, Gonville and Caius College, 509, ff.52ra-123rb), see S. Donati, op. cit., p. 421-432. 